\title{
The Connection between Extracurricular, Leisure Time Activities, Religiosity and the Reasons for Drop-out
}

\author{
Judit Váradi ${ }^{1}, Z^{Z}$ suzsanna Demeter-Karászi², Klára Kovács ${ }^{3}$ \\ Recommended citation:
}

Varadi, J., Demeter-Karaszi, Zs. \& Kovacs, K. (2019). The connection between extracurricular, leisure time activities, religiosity and the reasons for drop-out. Central European Journal of Educational Research, 1(1), 55-67.

\begin{abstract}
The interruption of tertiary education and the reduction in the dropout rate have been a central issue in educational sociology and education research. Exploring the possible reasons for dropping out can significantly contribute to reducing the trend. Our aim is to map the links between students dropping out and individual factors. Consequently, we investigate the connection between extracurricular and leisure-time activities, health behaviour and religiosity in relation to dropout. This is explained by the fact that one of the axioms of the literature on dropout is that belonging to civil networks usually strengthens the commitment to the successful completion of studies. In our analysis, we used the database created during the research carried out in 2018 by the Center for Higher Education Research and Development (CHERD-H) in the framework of project No. 123847 of the National Research, Development and Innovation Fund of Hungary, entitled The Role of Social and Organisational Factors in Student Dropout (DEPART 2018, N=605). Our results show that the neglect of study obligations among those who are disappointed in the course and further education is closely related to the shift in value preferences and an increase in the time spent with entertainment activities and partying. It can also be stated that students take part indifferent types of extracurricular activities only to a limited extent, and the different forms of participation in activities and religiosity are not related to the causes of dropout.
\end{abstract}

Keywords: dropout; extracurricular; leisure-time activities, religiosity

\section{Introduction ${ }^{4}$}

Nowadays, reducing the dropout rate is one of the top priorities in education policy. It is worth addressing the problem, not only in the Hungarian context, but in Europe as well, since massification has allowed a wider student population to enter the world of higher education, but at the same time has increased the dropout rate. It seems to be a problem not only in public education, but also in higher education, as it causes deficits at individual, institutional and social levels, too (Szemerszki, 2018).

The dropout from higher education can be defined in several ways. Some approaches do not consider it to be entirely negative dropout as it happens not only when the student's legal relationship ceases before acquiring the final certification (Karászi et al., 2018), but if the individual continues and/or completes his/her studies abroad this is also classified as dropout (Szemerszki,

\footnotetext{
${ }^{1}$ University of Debrecen, Debrecen, Hungary; judit.varadi.06@gmail.com

${ }^{2}$ University of Debrecen, Debrecen, Hungary; zsuzsanna.karaszi@gmail.com

${ }^{3}$ University of Debrecen, Debrecen, Hungary; kovacs.klarika87@gmail.com
} 
2018). In this case, the phenomenon is a breakpoint not at the individual level but at the institutional level (Karászi et al., 2018).

The focus of our study is based on students who have dropped out, and have left the higher educational institution without acquiring a certificate. Our aim is to map the links between students who drop out and individual factors. Consequently, we investigate the connection between extracurricular and leisure-time activities, health behaviour and religiosity in relation to dropout. This is explained by the fact that one of the axioms of the literature on dropout is that belonging to civil networks usually strengthens the commitment to the successful completion of studies (Pusztai, 2011; Pusztai, 2013). In fact, extracurricular and leisure activities imply leisure-time activities in some way; these activities may be targeted to developing certain skills, abilities or even talent. Consequently, they correlate with the accumulation of incorporated cultural capital (mainly in the former case) (Bourdieu, 1998) or can simply represent a form of recreation, rest and leisure; however, social activities intended to nurture relationships can also be part of these activities, even if these can occasionally lead to a higher prevalence of health-damaging behaviours (e. g. partying).

A special emphasis was placed on the role of music and sports activities and religiosity, and religious denomination, as several research results confirm their positive effect on academic achievement, and thus on dropout (Brohm, 2002; Kovács, 2015; Kovács 2018a; Pusztai, 2009; 2013).

\section{The impact of extracurricular, leisure-time activities and religiosity on academic achievement and dropout}

Improving employment by raising the level of education is a significant objective. Thus, interrupting higher educational studies and reducing dropout rates has been a central issue for years in education sociology and education research.

From this perspective, several studies have investigated the role of arts education at different levels of the education system (Thomas et al., 2015).

The literature on dropout highlights the positive impact on academic achievement of the engagement with the community and civil networks. Moreover, it also facilitates the successful completion of studies (Pusztai, 2011; Pusztai, 2013).

Mahoney and Cairns (1997) examined the impact of extracurricular activities in interrupting courses at different levels of education. It was found in their research that the ratio of school dropout of disadvantaged students was significantly lower among those who had previously participated in extracurricular activities. As a result of extracurricular activities, school progression changes, and participation in school sports clubs has a continuous positive effect on students' grades. Pusztai (2009) has demonstrated the positive impact of extracurricular activities on the effectiveness of Hungarian secondary and higher educational students. The author also notes that music studies and sports are effective extracurricular investments in terms of educational progress. Examining young people playing in a music band or ensemble, Kelstrom (1998) showed that students participating in group music were less absent from school, had a higher GPA, and had better results in mathematics. Based on our previous research, in which statistical and interview data were investigated, we examined why the dropout ratio is low among students taking part in artistic higher education (Szǘcs \& Váradi, 2018). During the analysis, it was found that music higher education forms a protective net that helps students to succeed, which is also the result of the years spent with the work involved in preparing them for music higher education. Individual education is the best way for the teacher and student to get to know each other better, and to develop the personal contact which depends on trust - that helps the student to cope with their problems. The reason for students' persistence in studying in musical arts courses is that the students are preparing for a career over many years, and in most cases, it is the realisation of a childhood dream.

Based on integration theory, Pascarella and Smart (1991) conducted longitudinal research, which found that athletes were more likely to graduate than non-athletes, and that this was affected by direct and indirect impacts operating in the background.

The sports activities of Afro-American and Asian students contribute significantly to institutional social integration, to higher satisfaction with the institution, and to self-confidence, 
which has an indirect influence on persistence and successful completion of studies. Among junior students, those taking part in sports activities were more likely to continue their studies in their own institutions, and male students were more likely to continue in other institutions, while students who engaged in non-sports activities, were more likely to drop out (Leppel, 2005). Several studies have confirmed that freshman university athletes are more likely to graduate even in disadvantaged groups such as Afro-Americans (Hawkins \& Mulkey, 2005; Hildenbrand et al., 2009).

According to a survey among Norwegian secondary school students (Wichstrøm, 1998), a high amount of alcohol consumption and regular drunkenness, as deviant behaviours, increase the risk of dropping out and reinforce the relationship with deviant peer groups. Concerning higher educational students, certain analyses in the context of partying and dropout indicate that when a student 'turns down the slope', he/she becomes increasingly desperate, disillusioned, dissatisfied, and less engaged in learning, as it becomes less important. In such a case, the student will search for displacement activities, such as partying or paid work that distract attention from study-related failures (Daley, 2010). Too much time spent with peers and friends in a place that is appropriate for conversation or partying, and where these activities have primary importance, indicates a value preference that assumes a hedonistic, carpe diem philosophy during higher educational years (Dávid \& Horváth, 2010) and may lead to dropout. According to research results conducted among sports school students, the complex health-consciousness index which includes physical, mental, and spiritual well-being, and health-behaviour showed a weak positive correlation with objective indexes (National Competence Measurement, literacy and mathematics results) and subjective (self-)evaluation of academic achievement (Kovács, 2018), which also means that the less health-conscious a student is, the worse the learning outcomes are.

Most of the studies do not deal with the effect of religiosity; however, it may also be important to discuss this effect, as there is more intensive worship among higher educational students (Pusztai, 2013). Opinions are divided on the question of how religious students can be identified. Certain elements in the literature examine these students as a privileged group, while others identify religious students of higher educational institutions as members of a risk group while their higher educational embeddedness is discontinuous and fragmentary (Pusztai, 2013). In some cases not only fragmentation, but imperfection also characterizes the integration of these students, leading to a weak integration (Pusztai, 2013). Based on this idea, it is interesting to examine the relationship between religiosity and dropout, since the discontinuous, fragmented embedding can lead to the possibility of uncertain goals, breakdown, failure, disappointment in learning goals, and dropout (Pusztai, 2013).

\section{Research design and Methods}

In this short section please explain as clear as possible, what kind of methods you used, why you chose these methods, and what the relevant circumstances of the data collection and the analyzing processwere. The more reliable this description is, the more impact you can make.

In the DEPART 2018 research, we examined dropped-out students who had completed their higher educational studies without graduating or qualifying from a further education institution in the last 10 years $(\mathrm{N}=605)$. The survey was done through snowball sampling. Consequently, our examination is an exploratory research. However, almost all training fields and almost all Hungarian higher educational institutions are represented in the database. The primary aim of the investigation was to discover what type of hindering factors led to a situation in which students did not complete their studies, and furthermore, what processes or decisions led them to this situation. The topics examined were school career, learning experiences, the relation of the family towards learning, career orientation, higher educational learning and social experiences, competing activities, and socioeconomic characteristics.

$53.8 \%$ of the respondents were women and $46.2 \%$ men, with a mean age of 29 years. Most of the participants currently live in a county town $(44.4 \%)$ or in a smaller town $(29.8 \%)$; $9.1 \%$ live in Budapest, while $16.7 \%$ live in a village or on a farm. $9.5 \%$ of their mothers/foster mothers had at most a primary educational certificate, $56.8 \%$ of them had a secondary level certificate and $33.7 \%$ had a 
higher educational degree. $7.9 \%$ of their fathers/foster father have completed only primary school, $66.9 \%$ of them had a secondary certificate, and $25.1 \%$ had a higher educational degree (Fényes et al., 2019).

The reasons for dropping out were examined through a block containing 21 questions. With cluster analysis, four dropout clusters could be identified: those dropping out due to financial reasons and work, those highlighting academic and institutional reasons, those highlighting various reasons and those disappointed in the course and further education itself (Fényes et al., 2019). ${ }^{5}$

In the framework of this research, we examined the proportion of dropped-out students participating in extracurricular activities during secondary and higher education, the frequency of various leisure-time activities, of smoking, substance use, drunkenness, and, in the context of religiosity, the different forms of worship and the denomination students belong to. Alongside the dimensions mentioned above, the groups created on the basis of their reasons for dropping out were compared. As analytical methods, descriptive statistics, correlation and difference analyses, by a measuring chi-square test with adjusted residuals, were carried out, where the decision level was determined at $5 \%$.

\section{Results}

\subsection{Extracurricular activities and the reasons for drop-out}

In our present study, we investigated the connections between incorporated cultural capital and dropout by exploring extracurricular artistic activity (Bourdieu, 1998). The question measured whether the respondent had taken part in the following activities for at least one year: learning to play a musical instrument, learning folk dancing, doing sports, fine arts, acting, literary creation, playing in an orchestra, singing in a choir.

64 to $74 \%$ of the examined sample did not take part in artistic activities while $36.9 \%$ of them did not pursue sports activities (Figure 1). However, it is remarkable that the prevalence of these extracurricular activities among dropped-out students has significantly reduced during the higher educational years compared to the prevalence of those pursued during the secondary educational years.

\footnotetext{
${ }^{5}$ The methodology and content of the creation of the clusters are introduced in the study by Fényes et al. in this volume. Thus, we do not discuss the detailed introduction of these in the present study due to considerations of space.
} 
Figure 1. The proportion of the students doing the various extracurricular activities (in high school and in higher education) (N=605). Source: DEPART 2018.

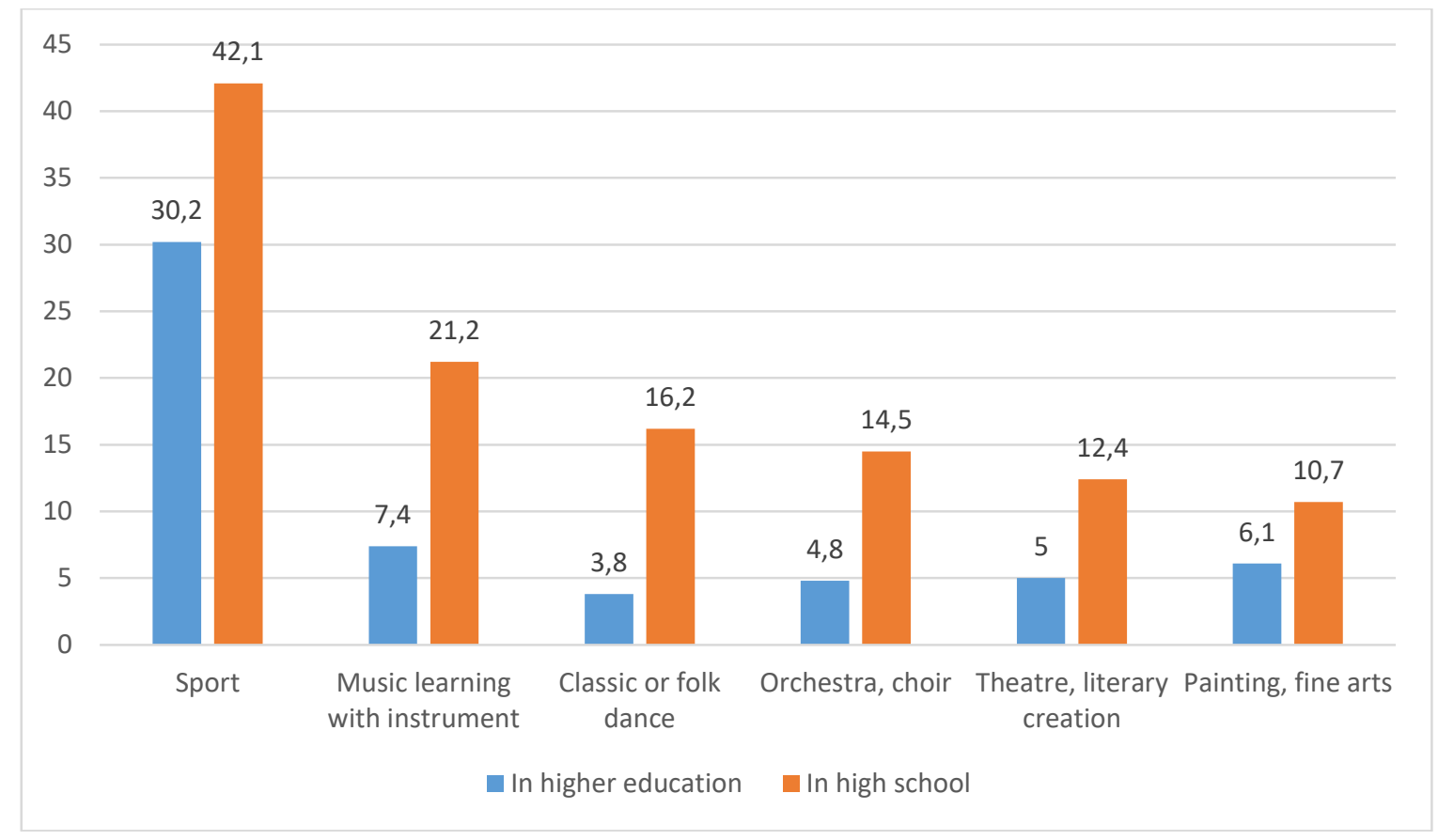

According to our analyses, extracurricular activities pursued during high school and university years did not show any significant connection with the clusters of students who dropped out.

\subsection{Leisure-time activities, health-behaviour and reasons for drop-out}

In our research, we also examined how frequently during the last semester of their higher educational studies dropout students took part in popular leisure-time activities such as Internet-related activities (surfing, playing games, and visiting social networks), chatting/meeting with friends, and partying, or participated in sports or religious events - the two most popular civil society activities (Pusztai, 2013) (Figure 2). 30\% of the respondents talked with friends every day, $22.1 \%$ of them several times per week, and $3.1 \%$ of them never, which may be due to a lack of friends. Approximately $28 \%$ of the respondents took part in parties at least weekly, $21 \%$ did so monthly, while every fifth dropped-out student went to a party once per year, and $16.5 \%$ of the respondents never did this kind of activity. Visiting sports programs was not so popular, as $35.5 \%$ of respondents never visited sports events and every fourth dropped-out student did this once per year. A relatively high proportion of students visited sports events weekly, i.e. $11.3 \%$ of the participants. Most of the students questioned visited community sites daily (53.6\%), surfed the Internet and played online (37.6\%), and the weekly regularity of these activities was also high (14.6\% and $20.2 \%$, respectively); but we can also see that $10.8 \%$ and $13.6 \%$ of the respondents never did these activities.

The highest proportion of the dropped-out students $(27.9 \%)$ has never pursued sport. Considering those students pursuing sport 2 or 3 times per year, it can be concluded that the proportion of those who never take part in sports activities is approximately one-third of the participants, which is a higher proportion compared to previous research results (Kovács, 2013; 2016).

$38.6 \%$ of the respondents pursued sport regularly, at least once per week, $15.2 \%$ did so on a monthly basis, and $12.1 \%$ did some exercise more often than once a week. 
Figure2. The frequency of the different leisure-time activities in the last semester $(\mathrm{N}=605)$. Source: DEPART 2018.

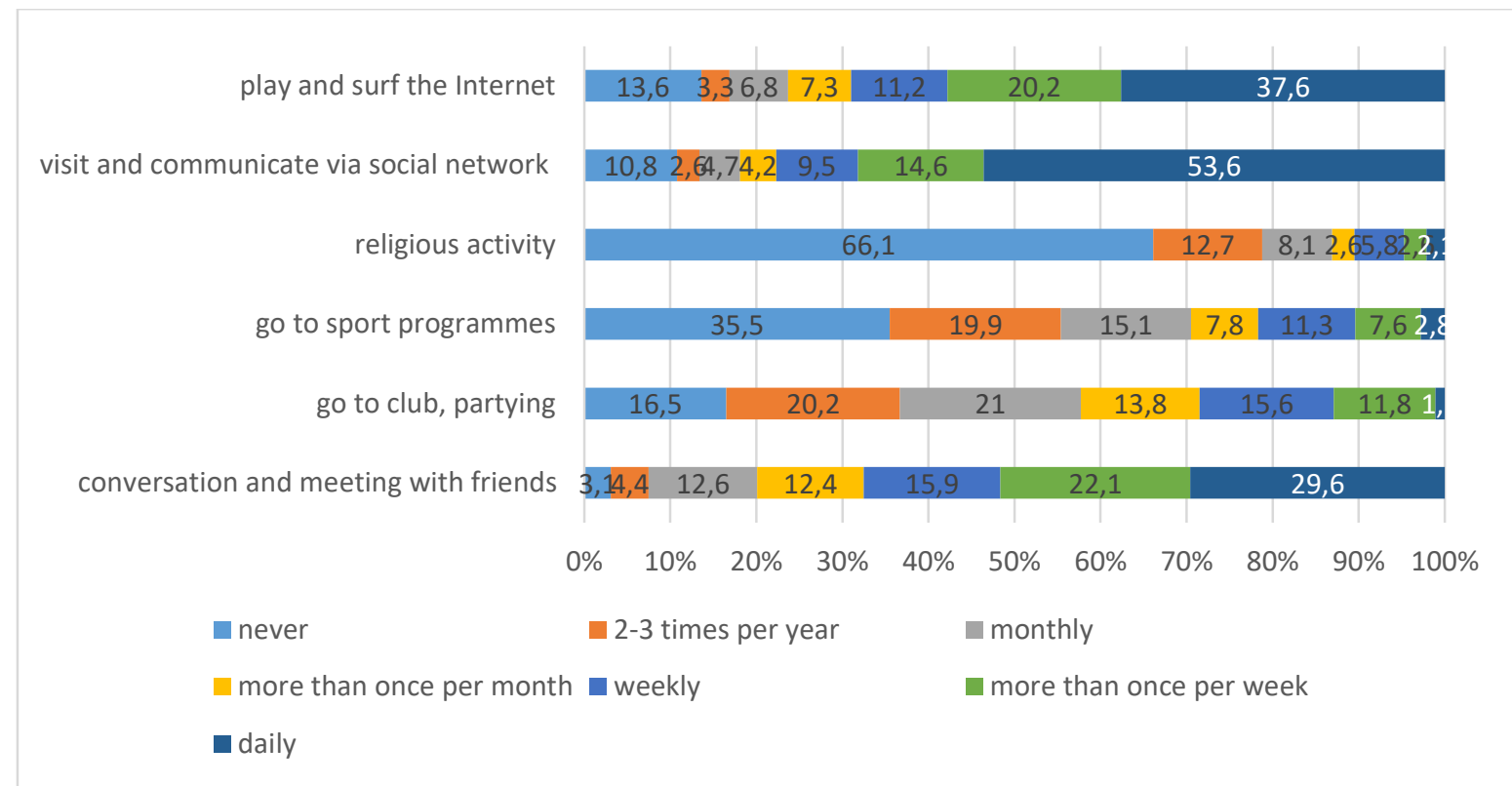

Among the different forms of health-risk behaviour, alcohol consumption, which is closely related to student life, represented the biggest threat (Cranford et al., 2009). Approximately one-third of the respondents have never been drunk; however, one-fifth of them were drunk on a weekly $(18.9 \%)$ or monthly basis (18.7\%). $10.3 \%$ were drunk more rarely, and $16.4 \%$ only a few times per year. The proportion of daily smokers was $29 \%$, and that of occasional smokers was $20.6 \%$, while others did not smoke during their studies. $92.4 \%$ of respondents reported never consuming illegal drugs, $7.1 \%$ did so occasionally and five students stated they used them daily.

In the subsequent part of the analysis, we examined the relationship between these variables and the different clusters of dropouts. The values of the leisure-time activities and sport frequencies were categorised in the following way: almost never, rarely, monthly and regularly (at least weekly). Among those students who drop-out as a result of disappointment with the course and further education in general we find the highest proportion $(77.8 \%)$ of those who reported meeting their friends the most often (this group of students were also those who answered 'never' the most infrequently $-3.2 \%$ ), followed by those dropping out for financial reasons and work $(69.5 \%)$, those highlighting academic and institutional reasons (63\%) and those dropping out for uncertain reasons $(61.7 \%)$. Our results clearly show that neglecting learning obligations is strongly associated with an overvaluation of the importance of entertainment and partying and a higher frequency of these activities. Furthermore, not only are those spending a lot of time with friends but also those going to parties regularly overrepresented among those disappointed with the course and further education, as $43.5 \%$ said they went to parties at least once a week. In their case, it is also noticeable that further education and university life were primarily related to social and entertainment activities, and to not meeting the requirements of the studies. Of course, we do not know whether they enrolled for higher education with this attitude or the initial disappointment related to their studies led to the prominent role of friends and partying in their lives.

It is noteworthy that the proportion of those who almost never went to parties is the highest (45.6\%) among the dropped-out students who had to stop their studies due to academic failure. We can see that these respondents took their study responsibilities very seriously in this regard as well.

Playing and surfing online was the least likely activity for students who dropped out for various reasons $(62 \%)$, and $27.3 \%$ of them almost never did this kind of activity, while it appeared in every tenth case among those dropping out for financial reasons and work, and those disappointed in the course and in further education. 
The financial demands of sport are also confirmed by the fact those doing sports activities regularly are underrepresented among those who have financial difficulties (26.9\%), unlike those in the group who are disappointed with the course and further education, where those who not only go to parties but also do regular physical activity were also more numerous (47.2\%). Only $24.8 \%$ of respondents reported almost never doing sports, while this proportion was $38.7 \%$ among those with financial difficulties and $37.7 \%$ among those highlighting academic and institutional reasons (Table 1). Concerning other recreational activities, no significant correlations could be found.

Table 1. The differences in the leisure-time activities in clusters createddue to the reasons for dropout $(\mathrm{p} \leq$ 0,05). Source: DEPART 2018.

\begin{tabular}{|c|c|c|c|c|c|}
\hline & & $\begin{array}{l}\text { Students } \\
\text { dropping } \\
\text { out due to } \\
\text { financial } \\
\text { reasons and } \\
\text { work }\end{array}$ & $\begin{array}{c}\text { Students } \\
\text { highlighting } \\
\text { academic } \\
\text { and } \\
\text { institutional } \\
\text { reasons }\end{array}$ & $\begin{array}{c}\text { Students } \\
\text { highlighting } \\
\text { various } \\
\text { reasons }\end{array}$ & $\begin{array}{l}\text { Students } \\
\text { disappointe } \\
\mathrm{d} \text { in the } \\
\text { course and } \\
\text { further } \\
\text { education }\end{array}$ \\
\hline \multirow{3}{*}{$\begin{array}{l}\text { Conversation } \\
\text { and meeting } \\
\text { with friends } \\
\mathrm{N}=544\end{array}$} & Almost never & 10.2 & 8.9 & 7.8 & 3.2 \\
\hline & $\begin{array}{l}\text { On a monthly } \\
\text { basis }\end{array}$ & 20.3 & 28.1 & 30.5 & 19 \\
\hline & $\begin{array}{l}\text { At least once a } \\
\text { week }\end{array}$ & 69.5 & 63 & 61.7 & 77.8 \\
\hline \multirow{3}{*}{$\begin{array}{l}\text { Having fun, } \\
\text { partying N=542 }\end{array}$} & Almost never & 39 & 45.6 & 39.2 & 21 \\
\hline & $\begin{array}{l}\text { On a monthly } \\
\text { basis }\end{array}$ & 28.8 & 37.4 & 35.9 & 35.5 \\
\hline & $\begin{array}{c}\text { At least once a } \\
\text { week }\end{array}$ & 32.2 & 17 & 24.8 & 43.5 \\
\hline \multirow{3}{*}{$\begin{array}{l}\text { Playing and } \\
\text { surfing the } \\
\text { Internet } N=542\end{array}$} & Almost never & 10.1 & 17 & 27.3 & 10.3 \\
\hline & $\begin{array}{l}\text { On a monthly } \\
\text { basis }\end{array}$ & 18.5 & 13.6 & 10.7 & 15.1 \\
\hline & $\begin{array}{c}\text { At least once a } \\
\text { week }\end{array}$ & 71.4 & 69.4 & 62 & 74.6 \\
\hline \multirow{3}{*}{$\begin{array}{l}\text { Pursuing sport } \\
\qquad \mathrm{N}=549\end{array}$} & Almost never & 38.7 & 37.7 & 33.8 & 24.8 \\
\hline & $\begin{array}{l}\text { On a monthly } \\
\text { basis }\end{array}$ & 34.5 & 27.2 & 21.4 & 28 \\
\hline & $\begin{array}{l}\text { At least once a } \\
\text { week }\end{array}$ & 26.9 & 35.1 & 44.8 & 47.2 \\
\hline
\end{tabular}


*In the case of the underlined values, the absolute value of the adjusted residual is higher than two

Our results differ from the generalized view that as a result of study failures and the lack of academic success, these students are searching for additional activities that distract their attention from the difficulties they face (e.g. they start partying, consuming alcohol and drugs). Drop-out can happen for a variety of reasons, and these statements are not valid for each person but for certain groups of dropped-out students. The proportion of those getting drunk at least on a monthly basis in the last semester of their studies was the highest among those who are disappointed in the course and studies (55.8\%), and parallelly, the proportion of those never getting drunk was the lowest in this cluster $(21.7 \%)$. However, the proportion of those never getting drunk was the highest among those who dropped out for various reasons, partly due to parenthood and other responsibilities $(44.2 \%)$. Nevertheless, this correlation is related not only to dropout but also to the fact that social activities, especially partying, are outstanding risk factors for getting drunk during higher educational years (Cranford et al., 2009; Kovács, 2018b). Furthermore, the proportion of those never using any substance is the highest among those highlighting various reasons for dropout (96.7\%), while the proportion of those using substance occasionally is the highest among those who reported dropping out for financial reasons (12.6\%). Concerning smoking, no significant correlation could be found (Table 2).

Table 2. The frequency of drunkenness and substance use in the clusters created due to the reasons for dropout $(p \leq 0,05)$. Source: DEPART 2018.

\begin{tabular}{|c|c|c|c|c|c|}
\hline & & $\begin{array}{c}\text { Students } \\
\text { dropping out } \\
\text { for financial } \\
\text { reasons and } \\
\text { work }\end{array}$ & $\begin{array}{c}\text { Students } \\
\text { highlighting } \\
\text { academic and } \\
\text { institutional } \\
\text { reasons }\end{array}$ & $\begin{array}{c}\text { Students } \\
\text { highlighting } \\
\text { various } \\
\text { reasons }\end{array}$ & $\begin{array}{c}\text { Students } \\
\text { disappointed } \\
\text { in the course } \\
\text { and further } \\
\text { education }\end{array}$ \\
\hline \multirow[t]{3}{*}{$\begin{array}{l}\text { Drunkenn } \\
\text { ess } N=552\end{array}$} & $\begin{array}{l}\text { Regularly (at least } \\
\text { one per month) }\end{array}$ & 40.8 & 32.2 & 29.2 & 55.8 \\
\hline & Occasionally & 25 & 30.2 & 26.6 & 22.5 \\
\hline & Never & 34.2 & 37.6 & 44.2 & 21.7 \\
\hline \multirow[t]{3}{*}{$\begin{array}{l}\text { Substance } \\
\text { use } N=548\end{array}$} & $\begin{array}{l}\text { Regularly (at least } \\
\text { one per month) }\end{array}$ & 1.7 & 0 & 0 & 0.8 \\
\hline & Occasionally & 12.6 & 4.1 & 3.3 & 10.2 \\
\hline & Never & 85.7 & 95.9 & 96.7 & 89.1 \\
\hline
\end{tabular}

*In the case of the underlined values, the absolute value of the adjusted residual is higher than two 


\subsection{Religiosity, denomination and drop-out}

Measuring religiosity is a cardinal issue for researchers. According to Tomka's definition, the 'yes' or 'no' options worked perfectly for a certain time and almost everyone was able to classify himself/herself into one of these groups. However, since the middle of the 1970s, the proportion of those choosing the response 'I do not know' and those refusing to answer have also increased. People were less able to describe their worldview and attitudes as just black-or-white. This encouraged the creation of a five-point scale (Tomka, 1990), which was also used in our questionnaire. The religious self-classification of the dropped-out students was the following: $37.9 \%$ reported being religious in their own way, followed by non-religious students at $25 \%$ and those definitely not religious at $11 \%$.In addition, $11 \%$ of the respondents said they were religious according to the church's teaching, and $6.9 \%$ were unable to decide whether they were religious or not. It can be detected that a large proportion of students reported being religious in their own way, which means that a large group of the respondents are insecure in their worldview. This data makes it clear that more sophisticated analytical procedures are necessary to analyse the religiosity of young generations (Földvári \& Rosta, 1998). According to the respondents, two-thirds of them never do any religious activities, and $12.7 \%$ do so once a year.

Figure 3. Self-rated religiosity among dropped out students (N=554). Source: DEPART 2018.

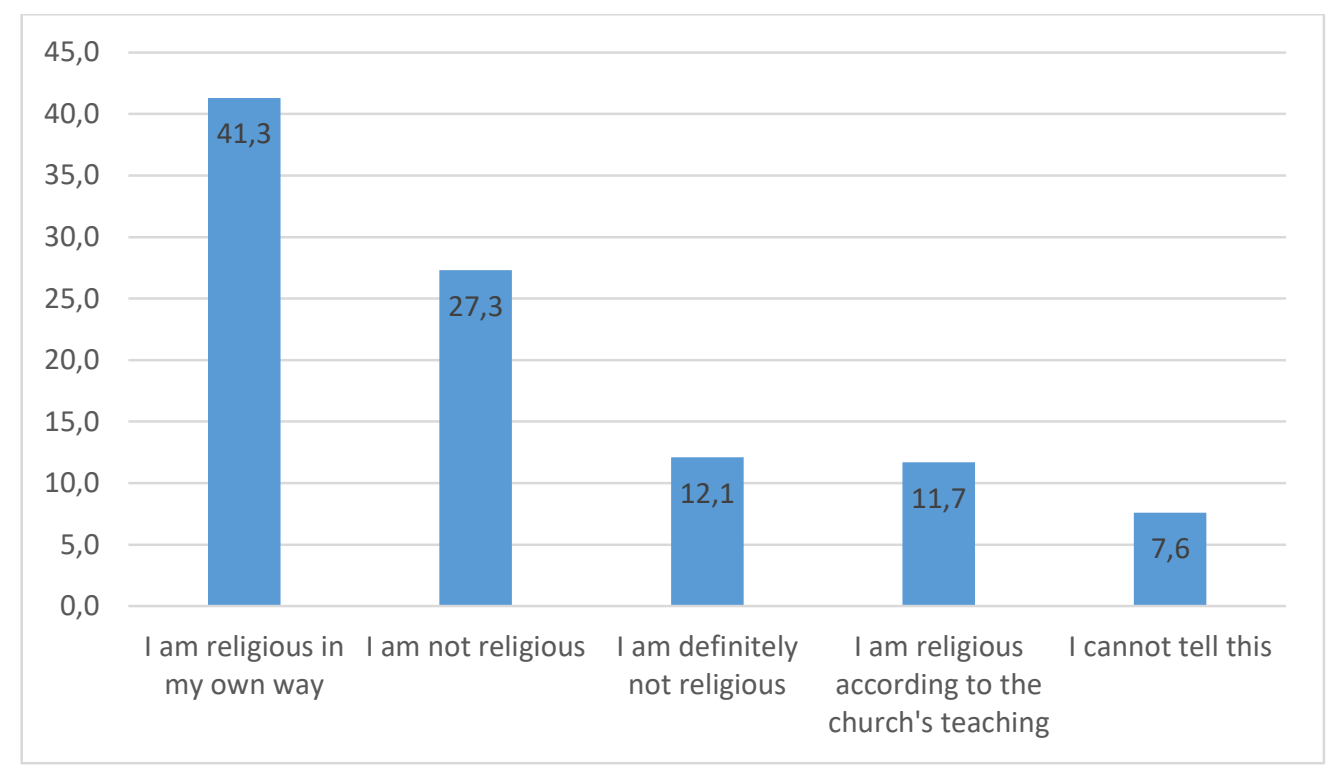

Since the norms of belonging to the community are influenced by denomination, we have examined this aspect, as well. $32.9 \%$ of the respondents belong to the Calvinist, $23 \%$ to the Roman Catholic and $8.4 \%$ to the Greek Catholic denominations $(\mathrm{N}=539)$. Those belonging to the Evangelical (Lutheran) $(1.8 \%)$, Unitarian $(0.5 \%)$, Baptist $(0,5 \%)$ and Orthodox $(0.2 \%)$ denominations are represented in a smaller proportion. $19.3 \%$ of the dropped-out students reported not belonging to any denomination; moreover, $2.5 \%$ have chosen other options, including Buddhist, atheist, Pentecostal, and non-baptized respondents, etc. 
Figure 4. The distribution of dropped out students according to their religious denomination $(\mathrm{N}=539)$. Source: DEPART 2018.

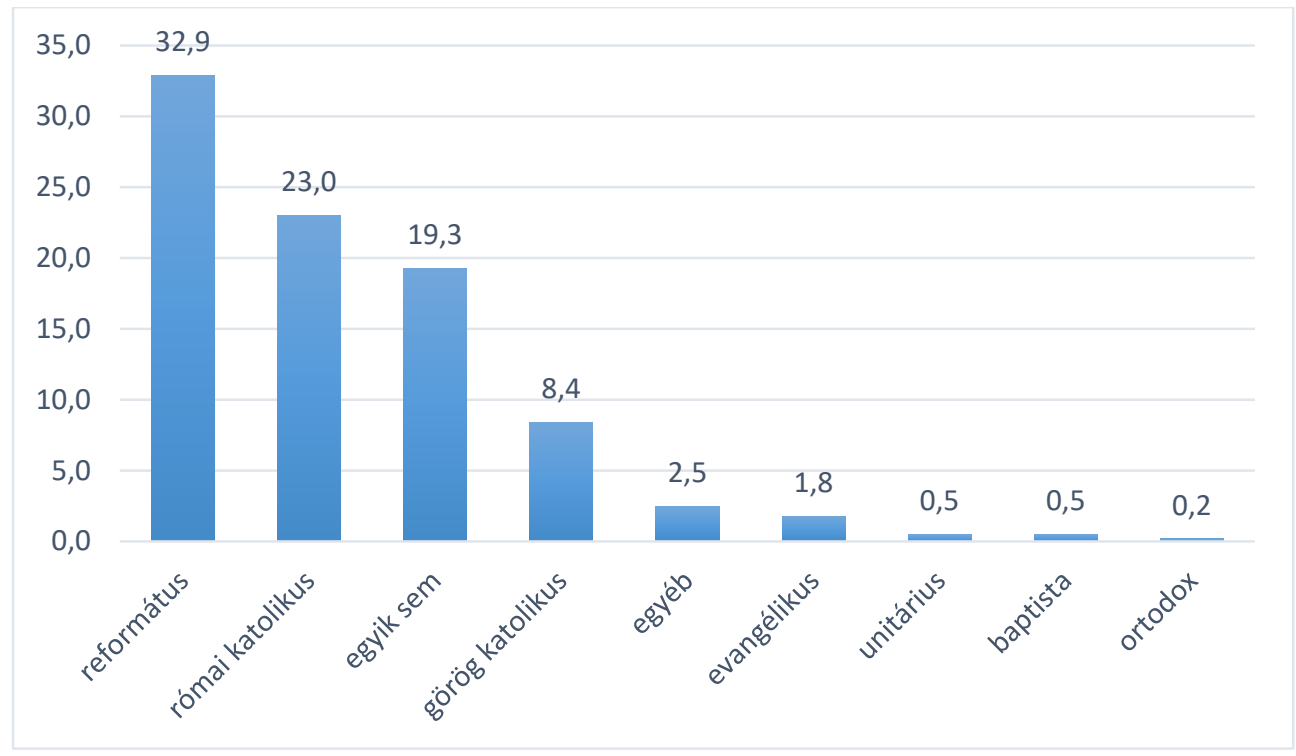

After investigating denominational affiliation, the frequency of going to a church or place of worship was also examined among dropped-out students $(\mathrm{N}=537)$. The proportion of students who never go to church $(31.7 \%)$ or go only once a year for major religious holidays $(39.7 \%)$ is the highest in the sample. The proportion of those going to a church or place of worship a few times per month $(8.4 \%)$, once per week $(6.4 \%)$ or several times per week $(2.5 \%)$ seemed to be smaller. Worship shows significantly different regional characteristics, thus no conclusions can be stated without controlling for this factor. However, if we compare the distributions to the national data, the proportion of those belonging to religious communities is no lower than that of higher educational students in general.

As the personal practice of religion can also support attitudes towards meeting the degree requirements, we were also interested in the regularity of prayer among the students investigated $(\mathrm{N}=533)$. Almost half of the dropped-out students (42.6\%) never pray, and $22 \%$ only do so on major holidays. This group is followed by students who pray at least once a day $(8.9 \%)$, and then by those who pray more than once per month $(7.4 \%) .6 .8 \%$ of the respondents pray more than once per day, $6.4 \%$ do so more than once per week and $2.1 \%$ once per week.

We examined the connection between the variables related to religiosity and the clusters of the dropped-out students as it is worth paying attention to the influence of religiosity during an investigation in to students' academic careers (Pusztai, 2013). We also compared the data for denomination, religiosity self-classification and frequent attendance at a church or place of worship with the different clusters of the dropped-out students, but no significant correlation could be found in any case. The question arises of whether religion is a risk factor for dropout or a protective factor against dropout during higher educational years and during an academic career. Since we could not make any comparisons among dropped-out and persistent students in this study, this question sets further research directions.

\section{Conclusion}

Exploring the leisure-time activities of dropped-out students, it can be clearly seen that they hardly participate in extracurricular activities. The decrease is also significant compared to secondary school extracurricular activities. This data is also considerable as both domestic and foreign research show that these activities, besides supporting persistence, have a positive effect on academic achievement and career (Brohm, 2002; Pusztai, 2011). Given that higher education students have a greater amount of free time that can be divided up independently, the result suggests that students are largely left alone by the institutions with this increased, self-distributing time. They 
hardly provide sufficient extracurricular activities, or if they offer such activities, they are not able to reach the mass of the student population, and may organize some of them on a profit basis, which makes participation inaccessible for certain students.

Our results show that, among students who are disappointed in the course and further education, neglecting study obligations is closely related to the shift in value preferences, and to the time spent with entertainment and partying. The lack of meaningful leisure-time activities and the increased free-time reinforce the risk of activities whose negative impact on academic work can be clearly demonstrated sooner or later.

Higher education institutions have failed to reflect on the change caused by the shift in the characteristics of young people. In higher education, students in late adolescence or post-adolescence can easily adapt to peer pressure when they do not receive other kinds of impulses.

During the evaluation of the results of the research, it could be stated that religiosity and worship show different regional characteristics. On the whole, the proportion of those belonging to a religious community is no lower among students who dropped out compared to Hungarian students in general. No significant correlation was found between the reasons for dropout and religiosity.

Funding: Project no. 123847 has been implemented with the support provided by the National Research, Development and Innovation Fund of Hungary, financed under the K-17 funding scheme.

Conflicts of Interest: The authors declare no conflict of interest.

\section{References}

1. Bourdieu, P. (1998). Gazdaságitőke, kulturálistőke, társadalmitőke [Economic capital, cultural capital, social capital]. In: Lengyel, Gy. \& Szántó, Z. (szerk.): Tókefajták: A társadalmi és kulturális erớforrások szociológiája. [Types of capital: Sociology of social and cultural resources.] Budapest, Aula. 155-176.

2. Brohm, B. A. (2002). Linking Extracurricular Programming to Academic Achievement: Who Benefits and Why? Sociology of Education, 75(1), 69-95.

3. Cranford, J. A., Eisenberg, D. \& Serras, A. M. (2009). Substance use behaviors, mental health problems, and use of mental health services in a probability sample of college students. Addictive Behaviors, 34.134-145.

4. Daley, F. (2010). Why College Students Drop out and What We Do about It. College quarterly, 13 (3). 1-5.

5. Dávid, J. \& Horváth, G. (2010). Munkaerő-piaci esélyek és pályaelhagyás a szakmai képzés végzőseinek körében. [Labor market opportunities and career abandonment among graduates of vocational courses.] Iskolakultúra, 20 (1).34-49.

6. Földvári M. \& Rosta G. (1998). A modern vallásosság megközelítésének lehetőségei. [Opportunities to approach modern religiosity.] Szociológiai szemle, 1.127-237.

7. Hawkins, R. \& Mulkey, L. M. (2005). Athletic investment and academic resilience in a national sample of African American females and males in the middle grades. Education and Urban Society, 38(1), 62-88.

8. Hildenbrand, K., Sanders, J., Leslie-Toogood, A. \& Benton, S. (2009). Athletic status and academic performance and persistence at a NCAA division I university. Journal for the Study of Sports and Athletes in Education, 3(1), 41-58.

9. Karászi, Zs., Pallay, K. \& Tóth D. A. (2018). A hallgatói jogviszony megszűnésével kapcsolatos szabályozás komparatív elemzése. [A comparative analysis of the regulation of the termination of student status.] In Pusztai G. \& Szigeti F. (szerk): Lemorzsolódás és perzisztencia a felsóoktatásban. [Dropout and persistence in higher education]. Debrecen, Debreceni Egyetemi Kiadó. 28-37.

10. Kelstrom, J. M. (1998). The untapped power of music: Its role in the curriculum and its effect on academic achievement [Electronic version]. National Association of Secondary School Principals Bulletin, 82. 34-33.

11. Kovács K. E. (2018). The relationship between health-awareness and academic achievement on a national representative sample. Hungarian Educational Research Journal, 8(4). (accepted manuscript).

12. Kovács K. (2013): Bourdieu, Hradilés Bandura elméleteinek vizsgálata a sportra vonatkozóan. A társadalmi, környezeti és egyéni tényezők hatása a partiumi region hallgatóinak sportolására.[Examining the theories of Bourdieu, Hradil and Bandura concerning sport. The impact of social, environmental and individual factors on the sporting activity of students in the Partium region.] Társadalomkutatás, 2.175-194. 
13. Kovács, $\quad$ K. (2015). $\quad$ A $\quad$ sportolási szokások $\quad$ és a tanulmányieredményességegyhatármentirégióhallgatóinakkörében.[Sporting habits and academic achievement among students in a cross-border region.] Educatio, 24(2), 130-138.

14. Kovács K. (2016). Közép-kelet-európaihallgatóksportolásánakszocio-kulturálisjellemzői.[Socio-cultural characteristics of athletes in Central and Eastern Europe.] In Kovács K. (szerk.). Értékteremtő testnevelés. Tanulmányok a testnevelés és a sportolás szerepéról a Kárpát-medencei fiatalok életében. Oktatáskutatás a 21.században 1 [Value-creating physical education. Studies on the role of physical education and sport among young people in the Carpathian Basin. Education research in the 21st century 1.] (pp.175-186). Debrecen: Debreceni Egyetemi Kiadó, CHERD-H.

15. Kovács K. (2018a). A sportolási szokások és perzisztencia kapcsolata magyarországi és romániai hallgatók körében. [The relationship between the sporting habits and persistency among Hungarian and Romanian students.]In Pusztai, G.; Szigeti, F. (szerk.): Lemorzsolódás és perzisztencia a felsőoktatásban. [Dropout and persistence in higher education]. Debrecen, Debreceni Egyetemi Kiadó. 154-169.

16. Kovács K. (2018b). A Comparison of Factors Influencing Health Risk Behaviour of College Students in the Countries of the Carpathian Basin. European Journal of Mental Health, 13 (2).184-210.

17. Leppel, K. (2005). The impact of sport and non-sport activities on college persistence of freshmen. Journal of College Student Retention: Research, Theory \& Practice, 7(3), 165-188.

18. Mahoney, J. L. \& Cairns, Robert B. (1997). Do extracurricular activities protect against early school dropout? Developmental Psychology, 33 (2).241-253.

19. Pascarella, E. T. \& Smart, J. C. (1991). Impact of intercollegiate athletic participation for African American and Caucasian men: Some further evidence. Journal of College Student Development, 32(2), 123-130.

20. Pusztai G. (2009). A társadalmi tóke és az iskola. [Social capital and school.]Budapest, Új Mandátum.

21. Pusztai G. (2011). A láthatatlan kéztól a baráti kezekig. Hallgatói értelmezóközösségek a felsőoktatásban. [The invisible hand to the hands of friends. Student Interpreting Communities in Higher Education.] Budapest, Új Mandátum.

22. Pusztai G. (2013). Hallgatói vallásosság és felsőoktatási beágyazottság.[Student Religiosity and Higher Educational Embeddedness.] Confessio, 37 (1).44-57.

23. Szemerszki M. (2018). Lemorzsolódási adatok és módszertani megfontolások. [Dropout data and methodological considerations.]In Pusztai G. \& Szigeti F. (szerk.). Lemorzsolódás és perzisztencia a felsőoktatásban. [Dropout and persistence in higher education]. Debrecen, Debreceni Egyetemi Kiadó. 15-27.

24. Szűcs T. \& Váradi J. (2018). Perzisztencia a zeneművészeti felsőoktatásban. A zeneművészeti képzés megtartóerejének vizsgálata. [Persistency in musical higher education. The investigation of the power of musical education.] In Pusztai G. \& Szigeti F. (szerk.): Lemorzsolódá sés perzisztencia a felsőoktatásban. [Dropout and persistence in higher education]. Debrecen, Debreceni Egyetemi Kiadó. 263-274.

25. Thomas, K. M., Singh, P. \& Klopfenstein, K. J (2015). Arts education and the high school dropout problem. Journal of Cultural Economics, 39 (4). 327-339.https://doi.org/10.1007/s10824-014-9238-x

26. Tomka M. (1990). Vallás és vallásosság. [Religion and religiosity.] In Andorka R., Kolosi T. \& Vukovich, Gy. (szerk.): Társadalmi riport. [Social report.]Budapest, Tárki. 534-555.

27. Wichstrøm, L. (1998). Alcohol intoxication and school dropout. Drug and Alcohol Review, 17 (4).413-421. 